\title{
Analysis of Nurses' Performance at Royal Prima Medan Hospital Use Analytic Hierarchy Process (AHP) Method and the 2020 Rating Scale Method
}

\author{
Lisdawaty Siregar ${ }^{1}$, Ermi Girsang ${ }^{2}$, Ali Napiah Nasution ${ }^{3}$ \\ ${ }^{1,2,3}$ Department of Magister Public Heath, Faculty of Medicine, University of Prima Indonesia, Medan, \\ Indonesia \\ Corresponding Author: Lisdawaty Siregar
}

\begin{abstract}
Nursing as a service area, is very laborintensive, making nursing management particularly challenging due to the diverse experiences and educational backgrounds of employees in health care settings. Types of work, as well as workers, challenge nursing managers to create the type of environment that facilitates quality nursing practice. The nurse manager has specific responsibilities for the hospital and the staff. Staffs, in turn, have responsibilities towards both the organization and the manager. The purpose of this study was to analyze the effect of nurses' performance using the Analytic Hierarchy Process (AHP) method and the Rating Scale method at the Royal Prima Hospital, Medan. This research is a descriptive-analytic study. The study was conducted from April to August 2020 at the Royal Prima Hospital Medan. The number of samples is 50 people. The results showed that there was a significant relationship between the performance of nurses using the Analytic Hierarchy Process (AHP) method and the Rating Scale at the Royal Prima Hospital Medan in 2020. The results of the multivariate test can be seen that the Analytic Hierarchy Process (AHP) method is the most influential. is a quantity. In the Rating Scale method, the most influential is quality. It is hoped that prioritization can be made to conduct a performance review to identify existing weaknesses so that improvements can be made continuously continuous for all services.
\end{abstract}

Keywords: Royal Prima Hospital; Nurse Performance; AHP; Rating Scale Method;

\section{INTRODUCTION}

The growth of hospitals has recently been accelerating, which has made competition among hospitals even tighter. 6 main resources in management influence the company's success in achieving its goals, namely capital, human resources, machines, materials, methods, and money. One resource that is very important in determining the successful use of other resources is human resources (Astuti et al 2018).

The element of the work implementer is one form of service activity and the spearhead of health services in hospitals is nurses. Factors that can affect performance are internal factors, which are internal factors that are related to a person's innate factors, for example, talent, personal characteristics, physical and psychological conditions as well as acquired factors. For example knowledge, skills, work ethic, work experience, and work motivation (Zahroti et al, 2018).

The nurse is a professional in a hospital that has an important role in the provision of health services. Therefore, the hospital where nurses work always makes various efforts aimed at improving the quality of nurse professionalism. Nursing is an integral part of the health service system and is one of the factors that determine the quality of health services. Therefore, it is necessary to pay attention to the performance of nurses in carrying out their 
duties and functions in providing health services to patients (Paramita Dewi, 2017).

Nurses must have skills in the change process, something strange or unnecessary happens when the general public and the environment are constantly changing, while nursing which is part of the community does not change in managing her professional life. A strategic step in dealing with nursing changes in the future is "the nurse should not harm yourself", which means that all nursing actions must meet the patient's needs without any negative risks that arise. Hence nursing Indonesia in the future needs to get top priority in nursing development (Aprilia Dewi, 2017).

Nurse performance is closely related to the quality of nursing services provided. The Directorate of Nursing Services of the Ministry of Health in collaboration with WHO (World Health Organization) 2004 examined several provinces in Indonesia which consisted of East Kalimantan, North Sumatra, North Sulawesi, West Java, and DKI Jakarta, the results showed that during the last 3 years there were $70.9 \%$ of nurses have never attended training, $39.8 \%$ of nurses in hospitals do non-nursing tasks, $47.4 \%$ of nurses who do not have clear and written job descriptions, there is no periodic monitoring and evaluation of the performance of nurses in particular.

From these conditions, the Directorate of Nursing Services with WHO and UGM in 2001 developed an indicator of performance assessment of nurses and midwives both at health centers and in hospitals called the Performance Management Development model which aims to improve the professionalism of nurses and midwives.

In terms of performance appraisal, of course, precise calculations are needed, one of which is using the Analytic Hierarchy Process (AHP) and Rating Scale methods. The function of the AHP method is to give weight to the factors derived from the main tasks and functions that will be used as assessment factors, while the method.
This rating scale requires less time, money, and training. The ratings are based on a certain scale from low to high. According to Riska, et al. (2019) Using the AHP method is an objective decision to help make objective decisions and for more efficient employee performance appraisals. While the use of the Rating Scale method is an assessment that is often used in general with a scale of 1-5.

Royal Prima Medan Hospital is one of the largest private hospitals and will be a referral center for the community, especially Medan City and other North Sumatra people. On February 14, 2013, the Head of the North Sumatra Provincial Health Office issued a Temporary Operational Permit to the Royal Prima Medan Hospital No. 440.442 / 1641 / II / 2014. On February 16, 2014 RS. Royal Prima Medan was inaugurated by the Deputy Governor of North Sumatra Province, Bpk. Ir. H. Tengku Erry Nuradi, M.Si with a Permanent Operational Permit from the North Sumatra Provincial Health Office signed by the Head of the North Sumatra Provincial Health Office, dr. Siti Hatati Surjantini, M.Kes.

Based on the above background, the researchers are interested in researching with the title "Analysis of Nurse Performance at Royal Prima Medan Hospital using the Analytic Hierarchy Process (AHP) Method and the 2020 Rating Scale Method".

\section{METHOD OF RESEARCH}

This type of research used in this research is descriptive with a quantitative approach. The location of this study was conducted at the Royal Prima Medan General Hospital and was carried out from April to August 2020. The populations in this study were all staff and workers who were and had worked at the Royal Prima Hospital. Nurse performance data collection techniques can be done using observation, in-depth interviews, and documentation. 


\section{RESULT}

From table 1 it can be seen that of the 50 respondents studied, the majority of respondents aged 31-40 years were 29 respondents with a percentage (58\%) and a minority aged $21-30$ years as many as 4 respondents (8\%), for the majority of respondents were female as many as 29 people $(58 \%)$ and a minority of respondents were male as many as 21 people (42\%), for the length of work the majority of respondents had worked longer than 1 year as many as 43 people (86\%) and a minority of respondents who have worked for 1 year as many as 7 people (14\%), for education the majority of respondents with an undergraduate education are 27 people (54\%) and a minority of respondents with a nurse education are 7 people (14\%).

Table 1. Frequency Distribution of Nurses at the Royal Prima Hospital Medan in 2020.

\begin{tabular}{|c|c|c|}
\hline Characterictic & (n) & $(\%)$ \\
\hline \multicolumn{3}{|l|}{ Ages } \\
\hline 21-30 Years & 4 & 8.0 \\
\hline $31-40$ Years & 29 & 58.0 \\
\hline 41-50 Years & 17 & 34.0 \\
\hline Total & 50 & 100 \\
\hline \multicolumn{3}{|l|}{ Genders } \\
\hline A Man & 21 & 42.0 \\
\hline Woman & 29 & 58.0 \\
\hline Total & 50 & 100 \\
\hline \multicolumn{3}{|l|}{ Time of W ork } \\
\hline 1 tahun & 7 & 14.0 \\
\hline$>1$ tahun & 43 & 86.0 \\
\hline Total & 50 & 100 \\
\hline \multicolumn{3}{|l|}{ Education } \\
\hline S1 & 27 & 54.0 \\
\hline D3 & 16 & 32.0 \\
\hline Ners & 7 & 14.0 \\
\hline Total & 50 & 100 \\
\hline
\end{tabular}

From tables 2 below it can be seen that of the 50 respondents studied, it was found that the majority of respondents answered that the quality was not good, namely 28 people $(56 \%)$ and a minority of respondents answered as good quality as 22 people (44\%), for the quantity the majority of respondents answered poorly as many as 27 people $(54 \%)$ and a minority answered well as many
23 people (46\%), for the use of time the majority of respondents answered poorly as many as 26 people (52\%) and a minority answered 24 people (48\%) well, for cooperation the majority of respondents answered unfavorably as many as 30 people $(60 \%)$ and minorities answered well as many as 20 people (40\%).

Table 2. Distribution of Nurse Performance at Medan Royal Prima Hospital in 2020

\begin{tabular}{|l|c|c|}
\hline Variables & Total (n) & Percentage (\%) \\
\hline Quality & & 44.0 \\
\hline a. Good & 22 & 56.0 \\
\hline b. Not Good & 28 & 100 \\
\hline Total & 50 & \\
\hline Quality & & 46.0 \\
\hline a. Good & 23 & 54.0 \\
\hline b. Not Good & 27 & 100 \\
\hline Total & 50 & \\
\hline Time User & & 48.0 \\
\hline a. Good & 24 & 52.0 \\
\hline c. Not Good & 26 & 100 \\
\hline Total & 50 & \\
\hline Cooperation & & 40.0 \\
\hline a. Good & 20 & 60.0 \\
\hline b. Not Good & 30 & 100 \\
\hline Total & 50 & \\
\hline
\end{tabular}

Based on the results of the study, it shows that there is a significant relationship between the performance of nurses using the Analytic Hierarchy Process (AHP) method at the Royal Prima Hospital Medan in 2020. The results of the multivariate test can be seen that in the Analytic Hierarchy Process (AHP) method the most effective is quantity. In the Rating Scale method, the most influential is quality.

A good nurse's performance is a bridge in answering the quality assurance of health services provided to patients, both sick and healthy. The main key in improving the quality of health services is nurses who have high performance. Work behavior (performance) produced by nurses can not be separated from the factors that influence it. Performance issues are a problem that will always be The role of nurses in carrying out health services is very important, especially as service providers, namely there are relatively more nurses compared to other health workers, so it is only natural that the performance of nurses plays a very important role in determining the image of the hospital / puskesmas. 
Therefore, nurses must always be maintained and improved as optimally as possible, and they need to get support from the hospital or other health agencies. Research conducted by Permata (2016) states that this research was carried out at Petala Bumi Hospital Pekanbaru in the inpatient ward of the internal medicine and pediatric ward. The research studied was the performance of nurses with four criteria, namely attitude, responsibility, knowledge and speed and accuracy of nurse performance, and then improvements were made using the Fuzzy AHP method, the aim was to determine which criteria were prioritized. Based on data processing and discussion, the main priority is the criteria for the attitude of the nurse, then continued with the knowledge of the nurse, the third priority is the speed and accuracy of the nurse.

The last priority is the criteria for the responsibility of the nurse when making mistakes in serving patients and these criteria are related to style the leadership, regulations or sanctions, and pressures that nurses face. The improvement of each of these criteria can be done by using the primary method in assigning nurses and holding a training and development system so that nurses can develop broader insights and experiences so that the skills or creativity of nurses will increase.

The results of research by Supriyadi (2017) state that motivation, work ethic, work environment, competence, and job satisfaction affect nurse performance with $\mathrm{p}$ values of $0.011,0.000,0.018,0.000,0.000$ $(\mathrm{P}<0.05)$. The multivariate test obtained the sig value. 0.000 , meaning that simultaneously the independent variable is related to nurse performance.

The performance of nurses as the spearhead of health services is a very important issue to be studied to maintain and improve the quality of health services. A good nurse's performance is a bridge in answering the quality assurance of health services provided to patients both sick and healthy. The main key in improving the quality of health services is nurses who have high performance.

\section{CONCLUSION}

Based on the results of research that has been conducted at the Royal Prima Medan Hospital, it can be concluded:

1. Based on the characteristics of respondents, the majority of respondents aged 31-40 years, based on gender, the majority of respondents are female, for the length of work the majority of respondents have worked $>1$ year, for education the majority of respondents have an S1 education.

2. Based on the nurse's performance, the majority of respondents answered that the quality was not good. For the quantity, the majority of respondents answered poorly. For the majority time use respondent answered not well. For cooperation, the majority of respondents answered poorly

3. There is a significant relationship between the performance of nurses using the Analytic Hierarchy Process (AHP) method and the Rating Scale at the Royal Prima Hospital, Medan in 2020.

4. The results of the multivariate test can be seen that the Analytic Hierarchy Process (AHP) method has the most influence is quantity. In the Rating Scale method, the most influential is quality.

\section{REFERENCES}

1. Astuti, Rini. Lesmana, O., P., A. 2018. Pengaruh Motivasi dan Beban Kerja terhadap Kinerja Perawat pada Rumah Sakit Umum Mitra Medika Medan. Universitas Muhammadiyah Sumatera Utara.

2. Aprilia, Friska. 2017. Pengaruh beban Kerja, Stres Kerja, dan Motivasi Keerja Terhadap Kinerja Perawat Rumah Sakit Islam Ibnu Sina Pekanbaru; JOM Fekon, Vol. 4, No. 1. Universitas Pekanbaru, Riau

3. Paramitadewi, K. F. 2017. Pengaruh Beban Kerja Dan Kompensasi Terhadap Kinerja Pegawai Sekretariat Pemerintah Daerah Kabupaten Tabanan. E-Jurnal Manajemen, 6(6). 
Lisdawaty Siregar et.al. Analysis of nurses' performance at Royal Prima Medan Hospital use analytic hierarchy process (AHP) method and the 2020 rating scale method.

4. Supriadi, Apip, dkk. 2018. Analytical Hierarchy Process (AHP) Teknik Penentuan Strategi Daya Saing Kerajinan Bordir. Yogyakarta: Deepublish.)

5. Zahroti NM, Chalidyanto. Pendekatan PDSA Untuk Perbaikan Proses pada Indikator Sasaran Keselamatan Pasien di Rumah Sakit. Jurnal Administrasi Kesehatan Indonesia. 2018;6(2)

How to cite this article: Siregar L, Girsang E, Nasution AN. Analysis of nurses' performance at Royal Prima Medan Hospital use analytic hierarchy process (AHP) method and the 2020 rating scale method. International Journal of Research and Review. 2021; 8(3): 20-24. 